\title{
Structural organization of the social paper wasp (Hymenoptera: Polistinae) assemblage along a latitudinal gradient in the Atlantic Rainforest: correlating fauna partitioning to biodiversity centers
}

\author{
Eduardo Fernando dos Santos ${ }^{1} \cdot$ Fernando Barbosa Noll $^{1}$. \\ Carlos Roberto Ferreira Brandão ${ }^{2}$
}

Received: 13 January 2016/ Accepted: 1 July 2016/Published online: 11 July 2016

(C) Springer International Publishing Switzerland 2016

\begin{abstract}
Based on species endemism, three biodiversity centers, called "Ecological Corridors" have been proposed as one of the main conservation strategies for the Atlantic Rain Forest. This study tested whether the organization of the social paper wasp assemblage fits those centers. A standardized protocol was used for sampling the social paper wasp fauna. The structural organization was estimated by Nonmetric Multidimensional Scaling (NMDS) based on the similarity indexes of Sorensen (qualitative data) and Morisita-Horn (quantitative data). Regressive models were applied to the first axes' site scores of the NMDS, to the latitudinal and altitudinal variations, and to the speciation and immigration probabilities predicted by the neutral theory for a metacommunity. Our results indicated that the social paper wasp assemblage is organized in a continuum, with two distinct biodiversity centers. The organization of the assemblage along the gradient was dependent on latitudinal and altitudinal variations and their interactions, and also on the speciation and immigration probabilities. Several studies have demonstrated that the current biodiversity patterns of the Atlantic Forest might be explained by the past climate and, consequently, by the
\end{abstract}

Electronic supplementary material The online version of this article (doi:10.1007/s10841-016-9891-9) contains supplementary material, which is available to authorized users.

Eduardo Fernando dos Santos

efs.wasp@gmail.com

1 Departamento de Zoologia e Botânica, Instituto de Biociências, Letras e Ciências Exatas da Universidade Estadual Paulista "Júlio de Mesquita Filho", Rua Cristóvão Colombo, 2265, Jd. Nazareth, São José Do Rio Preto, SP 15054-000, Brazil

2 Museu de Zoologia da Universidade de São Paulo, Av. Nazaré, 481. Ipiranga, São Paulo, SP CEP 04263-000, Brazil connection between the Amazon and the Atlantic Forest. In addition, speciation and immigration probabilities strongly influence the compositional and structural variations of the social paper wasp assemblage along the latitudinal gradient.

Keywords Atlantic Forest - Epiponini - Mischocyttarini · Polistini · Predatory wasp $\cdot$ Vespidae

\section{Introduction}

The Atlantic Forest is one of the richest and most threatened biomes of the world; thus, it has been recognized as a biodiversity conservation "hotspot" (Myers et al. 2000; Mittermeier et al. 2004). Few conservation hotspots are as threatened and diverse as this megadiverse biome (Laurence 2009). Despite recent efforts to conserve it, the anthropogenic impacts are still intense (Morellato and Haddad 2000; Fundação SOS Mata Atlântica and INPE 2014). Currently, only approximately $12.5 \%$ of the original forest cover remains (Fundação SOS Mata Atlântica and INPE 2014), and the majority of the preserved areas are located along the Brazilian coast, mainly in the southeastern region (Morellato and Haddad 2000). This biome includes two main vegetation types: the Atlantic Rain Forest along the Brazilian coast and the Atlantic Semi-deciduous forest covering the South American Central Plateau (Morellato and Haddad 2000).

The Atlantic Rain Forest has been considered to be a biogeographical province of the Neotropical Region based on insect distributions, including the fauna of Aculeate Hymenoptera (Willink 1988; Morrone 2006). The history of the Atlantic Forest is marked by several forest expansion 
and retraction events (Por 1992; Costa 2003) modulated by the climatic history of the region (Carnaval and Moritz 2008). Previous climate changes have been considered to be some of the main determinant factors of biodiversity patterns (Araújo et al. 2008; Carnaval and Moritz 2008; Leprieur et al. 2011; Sandel et al. 2011). The sucessive forest expansion and retraction events resulted in connections between the Amazon and Atlantic Forests at different latitudes and times (Bigarella et al. 1975; Prance 1987; Por 1992; Costa 2003), thus influencing the distribution of species and consequently contributing to the current biodiversity pattern. However, several other intrinsic factors of latitudinal gradients, such as variations in productivity and temperature (Hawkins et al. 2003; Ye et al. 2014; Barthelemy et al. 2015), have also influenced such patterns, characterizing the latitudinal variation as one of the main geographic components responsible for the high biodiversity in the Atlantic Rain Forest (Ab'Saber 2003; Pinto and Brito 2005).

Substantial efforts have been made to protect the Atlantic Rain Forest remnants and to restore deforested areas (Conservation International-Brazil et al. 2000; Fonseca et al. 2003; Galindo-Leal and Câmara 2003; Tabarelli et al. 2005). Based on a holistic and sustainable view, three biodiversity centers have been proposed as a conservation strategy for the Atlantic Rain Forest based on the endemic areas of birds, butterflies, and primates (Silva and Casteleti 2003; Ribeiro et al. 2009): (1) the South Center, which is located between northern state of Rio de Janeiro and the southern border of the Atlantic Rain Forest and includes the largest conservation areas and the longest continuous forest extension; (2) the Central Center, which ranges from central-eastern state of Bahia to southern state of Espírito Santo and includes the greatest diversity of vascular plants in the world, as well as a large number of endemic animal species; and (3) the North Center, which is the most neglected area, with small and quite isolated conservation areas in northeastern Brazil (Conservation InternationalBrazil et al. 2000; Silva and Casteleti 2003; Fonseca et al. 2003; Ayres et al. 2005; Tabarelli et al. 2005, 2010). These biodiversity centers are called "Ecological Corridors" by Fonseca et al. (2003), Silva and Casteleti (2003) and Ayres et al. (2005), and the main organizations involved in the protection of the Atlantic Forest, such as the Brazilian Biodiversity Fund, Conservation International-Brazil and SOS Mata Atlântica Foundation. The biodiversity center approach seeks to provide, through appropriate public policies, a practical and effective solution for maintaining biodiversity and large-scale ecological processes in extensive areas of habitat in their original condition (CEPF 2001).

The latitudinal gradients are established by a combination of physical, ecological, historical, evolutionary, and stochastic forces, which determine species spatial heterogeneity (Willig 2001; Gaston 2003; Willig et al. 2003; Goldberg and Lande 2007; Buckley and Jetz 2008). Such variations influence species distribution, which in turn modulates biological diversity (Huston 1994; Gaston and Williams 1996; Gotelli and Graves 1996). The spatial heterogeneity of the latitudinal gradients may reflect biogeographical patterns, which may be properly interpreted only within the broad context of regional and historical influences (Ricklefs 2004, 2007; Wiens and Donoghue 2004). According to Pennington et al. (2004) and Carnaval and Moritz (2008), current patterns of biodiversity of the Atlantic Forest are predicted by the climatic history. Climate change through time modulates the extinction vulnerability of populations (McKinney 1997; Schwartz et al. 2006), so that extinction balances immigration at the local community level and is balanced by speciation at the regional level (metacommunity) (Munoz et al. 2008), although it rises locally (Vellend 2010). In this way, diversity patterns could be built up by colonization-extinction dynamics (Ricklefs 2007), such as has been proposed by the island biogeography (MacArthur and Wilson 1967) and Neutral (Caswell 1976; Hubbell 2001) theories for biodiversity. In addition, Leibold et al. (2004) and Vellend (2010) highlighted that extinction can also be a result of stochastic forces, driven by ecological drift as has been predicted by the neutral theory (Caswell 1976; Hubbell 2001). Despite the large number of studies, the diversity pattern and distribution of Polistinae remain poorly understood at the regional level. All species of this group are predators of other insects (Wenzel 1998), and some of them are facultatively necrophagous (Sarmiento 2004). These wasps build elaborate nests from plant fibers or mud (Richards 1978; Wenzel 1998) that can be extremely large, with hundreds of thousands or even more than a million individuals (Zucchi et al. 1995). Due to their biological requirements, the success of the forest Polistinae species can be linked to the ecosystem support capacity, so that some species have been regarded as a keystone species (Oliveira et al. 2010). Due to these aspects, the abundance of predatory wasps might be influenced by forest fragmentation and isolation (Coudrain et al. 2013; Santos et al. 2014).

The present study tests whether the structural organization of the social paper wasp assemblage fits the biodiversity centers proposed for conservation of the Atlantic Rainforest. We used a metacommunity approach, modeling the structural organization of the social paper wasp assemblage to the altitudinal and latitudinal data and also the immigration and speciation probabilities predicted by the neutral theory proposed by Hubbell (2001). This latter aspect was used to test the influence of the neutral paradigm on the assemblage dynamic. 


\section{Methods}

\section{Study areas}

This study was carried out in 17 conservation areas of the Atlantic Rain Forest located between latitudes of $7^{\circ}$ and $27^{\circ}$ and close to the Brazilian coast (Fig. 1). According to an updated Köppen-Geiger climatic classification (Peel et al. 2007), the two main climates along the Brazilian coast are (1) tropical, including three strands between the states of Rio Grande do Norte and Espirito Santo, comprising (a) rainforest, (b) monsoon, and (c) savannah; and (2) temperate, which also includes three strands located between the states of Rio de Janeiro and Rio Grande do Sul characterized by (a) a dry winter and a hot summer, (b) no dry season and a hot summer, and (c) no dry season and a warm summer $(\neq$ hot summer). Moreover, the Atlantic Rain Forest vegetation is classified differently along the

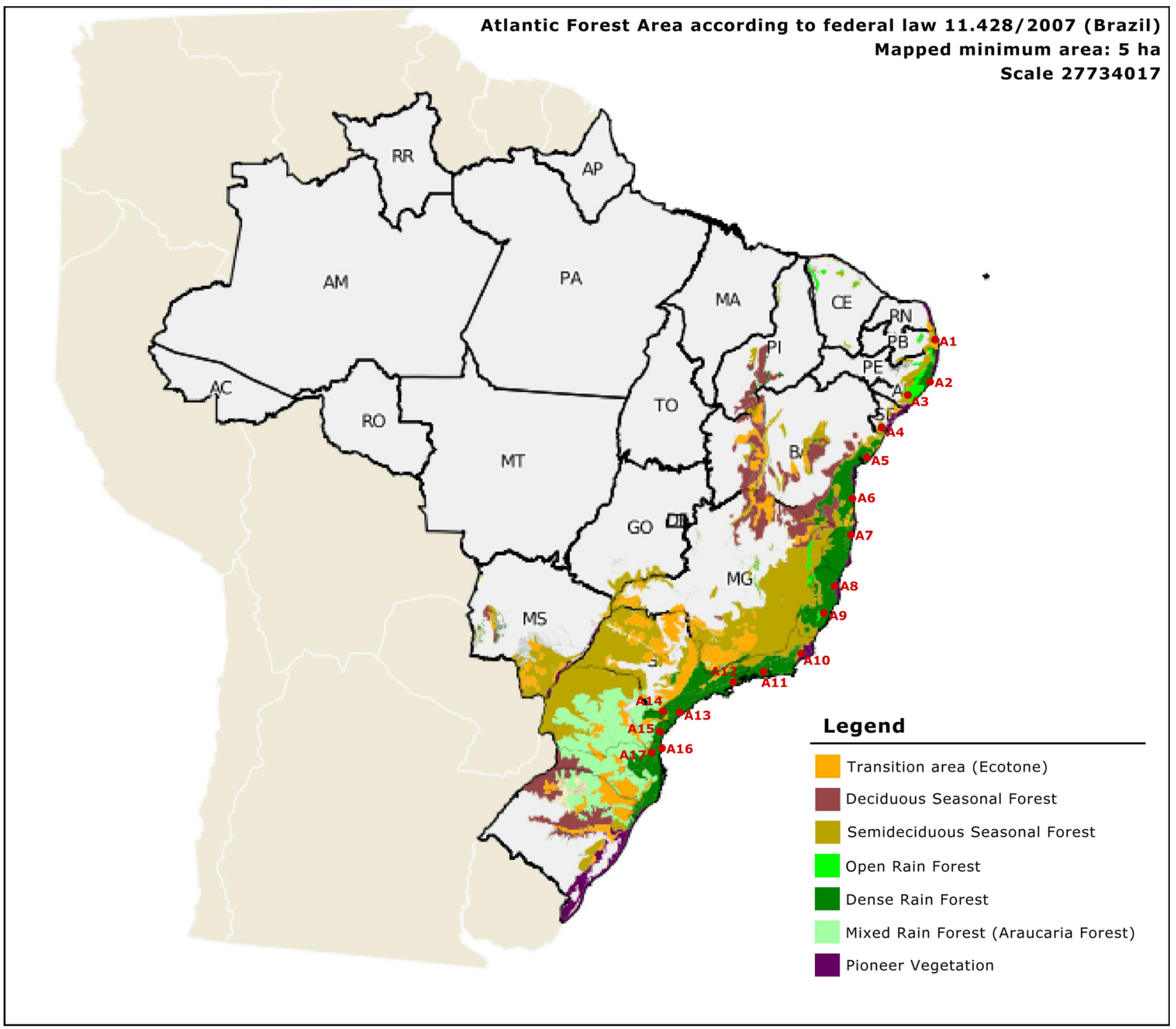

Fig. 1 Map of South America showing the sampled areas of the Atlantic Rain Forest along the latitudinal gradient close to the Brazilian coast. A1 Mata do Buraquinho, João Pessoa, PB; A2 Horto Florestal dois Irmãos, Recife, PE; A3 Biological Reserve of Pedra Talhada, Quebrangulo, AL; A4 Crasto, Santa Luzia do Itanhy, SE; A5 Ecological Reserve of Sapiranga, Mata de São João, BA; A6 Mata Esperança, Ilhéus, BA; A7 Ecological Station Pau Brasil, Porto Seguro, BA; A8 Biological Reserve of Sooretama, Linhares, ES; A9 Biological Station Santa Lúcia, Santa Teresa, ES; A10 State Park of
Desengano, Santa Maria Madalena, RJ; A11 Biological Reserve of Tinguá, Nova Iguaçu, RJ; A12 State Park of Serra do Mar's Picinguaba Center, Ubatuba, SP; A13- State Park Intervales, Ribeirão Grande, SP; A14- Ecologial Station Juréia-Itatins, Peruíbe, SP; A15State Park of Pau Oco, Morretes, PR; A16- Center of Environmental Studies and Research of Vila da Glória, São Francisco do Sul, SC; A17- Center of Environmental Studies and Research of Rugendas, São Bento do Sul, SC (see Online Resource 1 for more information) 
latitudinal gradient (Fig. 1, and see Online Resource 1 for more information).

\section{Sampling design}

The social paper wasp fauna was sampled in the rainy seasons from 2000 to 2002. The standardized collection protocol included two techniques that are commonly used to sample flying Hymenoptera: (1) Malaise and (2) Möericke (yellow pan) traps, and (3) vegetation sweeping based on Noyes' (1989) methodology. Each Möericke sample consisted of five yellow pans, each with a diameter of $124 \mathrm{~mm}$. Both the Malaise and Möericke techniques were applied along two transects of 500 meters, one of which was along a track inside the forest and the second transect was located in the forest proper, i.e. under the tree canopy with no obvious track. Both transects started inside the forest, at least $100 \mathrm{~m}$ from the edge. Malaise traps were set-up along the transects at $100 \mathrm{~m}$ intervals, whereas Möericke traps were set-up at $50 \mathrm{~m}$ intervals. Thus, five Malaise trap samples and ten Möericke trap samples were obtained from each transect, with a total of 10 Malaise trap samples and 20 Möericke trap samples for each conservation area. Both techniques were applied simultaneously for six consecutive days. Vegetation sweeping was carried out along two transects located along two different tracks inside the forest. The transects used were different for the three collection techniques. All the collected specimens were deposited in the Museu de Zoologia da Universidade de São Paulo (MZUSP_Zoological Museum of the University of São Paulo), São Paulo, Brazil.

\section{Data analysis}

The organization of the social paper wasp assemblage was analyzed based on structural (abundance data) and compositional (presence/absence data) similarities among the areas. For these analyses, Nonmetric Multidimensional Scaling (NMDS) with two dimensions and based on the Horn-Morisita index was applied to the relative abundance data, and the Sorensen index was applied to the species presence/absence data. The species composition is one of the components of the community structure, and analyzing it singly provides a deeper understanding on the community structural variation. These two aspects can represent diverse scenarios, since a set of local communities can be identical in species composition, but have different structure due to variation in abundance (Maaß et al. 2014). The NMDS was preferred, over other approaches, because it allows the preservation of ordering relationships among objects, and due to its flexibility on the application of the appropriate distance index (Gower 1987, Legendre and Legendre 1998). Moreover, it is more efficient than other methods in eliminating deformations, in which groups that are distinct in a third or higher dimension may be packed in the ordination plane with two dimensions, and because of this other methods may fail to discriminate the gradients (Legendre and Legendre 1998), such as observed by Minchin (1987), Anderson and Willis (2003) and Brehm and Fiedler (2004).

The linear mixed models were used to model the two NMDS axes' site scores (dependent variables) on the basis of the latitude, altitude and/or their interaction (independent variables). This modeling included the type of forest, which was obtained from the classification maps of the vegetation cover provided by MMA (2006) (Fig. 1, and see Online Resource 1 for more information), as a random effect, since areas with different vegetation tends to have different fauna, and consequently areas with the same forest types are more similar among them than those ones with different vegetation. In addition, the five most popular spatial correlation structures (exponential, gaussian, linear, rational quadratic and spherical) were included in the model fitting. The best-fitting models were selected from the AIC values.

The speciation probability $(v)$, based on the point-mutation mode, and the immigration probability $(m)$ were estimated from the Unified Neutral Theory of Biodiversity proposed by Hubbell (2001), using the relative abundance of species. The point-mutation mode is the only one that provides suitable speciation estimation from species abundance data obtained locally (Etienne et al. 2007; Haegeman and Etienne 2010; Rosindell et al. 2010; Etienne and Haegeman 2011). The $m$ estimation was based on Munoz et al.'s (2008) approach, which uses the Etienne's sampling formula (Etienne 2007). Both $m$ and $v$ (dependent variables) were also modeled on the basis of the latitude, altitude and their interactions (independent variables) using Generalized Additive Mixed Models (GAMMs) that included the forest type as random effect and those five spatial correlation structures. The choice of the best-fitting models was based on the AIC values, the adjusted coefficient of determination $\left(\operatorname{adj}-R^{2}\right)$ and the significant estimates of the independent variables. Analyses of variance (ANOVA) were applied to the competitive models.

Following the results obtained from these models, and also from the two-axis NMDS modeling, the NMDS first axes' site scores were associated to the latitudinal and altitudinal variations, to their interactions (independent variables), and to the independent covariates $m$ and $v$ on the logarithmic scale. The logarithmic scale was used to reduce any discrepancy in $m$ and $v$ in their relationship with the ordered NMDS' axes. The modeling was performed with GAMMs, considering the independent variables in the parametric treatment, while the covariates $m$ and $v$ were incorporated in the nonparametric part, allowing a possible 
nonlinear adjust of these two covariates. In addition, the GAMMs also included the five most used spatial correlation structures and the type of forest as a random effect. The selection of the best-fitting models was also based on the AIC values, adj- $R^{2}$ and the significant estimates of the independent variables, with application of the ANOVA to the competitive models.

Finally, null models based on 30,000 simulations and on the algorithm r2dtable were applied to the Morisita-Horn and Sorensen distances and to the NMDS to test whether average similarities among areas and the positions of the localities and species in the multidimensional space are results of undetermined random forces. In addition, Analyses of Similarities (ANOSIM) were performed to test whether the structural organization and composition of the social paper wasp assemblage, from each biodiversity center, are significantly distinct.

All statistical analyses were performed using the program R version 3.1.2 (R Development Core Team 2014), and the R packages: vegan version 2.0-8 (Oksanen et al. 2013), mgcv version 1.7-26 (Wood 2014), nlme (Pinheiro et al. 2015), and untb (Hankin 2015).

\section{Results}

\section{Assemblage composition and structure}

In total, 21 species of social paper wasp were sampled along the latitudinal gradient; most of the wasps belonged to the Epiponini (14 species). Agelaia angulata (Fabricius), A. flavipennis (Ducke), A. multipicta (Haliday), A. vicina (de Saussure), and Angiopolybia pallens (Lepeletier) were the five most abundant species, with more than 50 individuals collected. Four species were recorded at only one conservation area: Apoica flavissima Van der Vecht in the State Park of Desengano, Mischocyttarus montei Zikán and Polybia minarum Ducke in the State Park of Serra do Mar's Picinguaba Center, and Polistes melanosoma Saussure in the State Park of Pau Oco.

The NMDS based on the community structure (quantitative data) and composition (qualitative data) suggested that there was a gradual species substitution in the assemblage along the latitudinal gradient (Fig. 2). The linear models indicate that the first axes of the NMDS estimated with both the Sorensen and Morisita-Horn approaches were associated with the latitudinal variation, while the second axes of both analysis were not explained by any of the explanatory variables or their interaction combination (Table 1, and see Online Resource 2 for more information). In addition, the occurrence and structure turnover represented by the first axes of the NMDS were strongly explained by the latitudinal and altitudinal variations, by the interaction of these two variables and also by $v$ and $m$ (Table 1, see Online Resource 3 for details). The site scores of the first axis of the NMDS, based on the relative abundance, showed a linear relationship with $v$ (Fig. 3); in contrast, the site score observed for the NMDS based on the qualitative data was non-linear (Fig. 3). The first axis scores of the NMDS based on quantitative data and the score based on qualitative data showed non-linear relationships to $m$ (Fig. 3).

Based on the AIC values, variations in $m$ would be explained solely by the altitudinal variation with a spherical spatial correlation structure (SSCS), but the most complete model, which included latitude, altitude and their interactions, with a SSCS was the best-fitting model, since it had the highest adj- $R^{2}$, with all significant relationships between

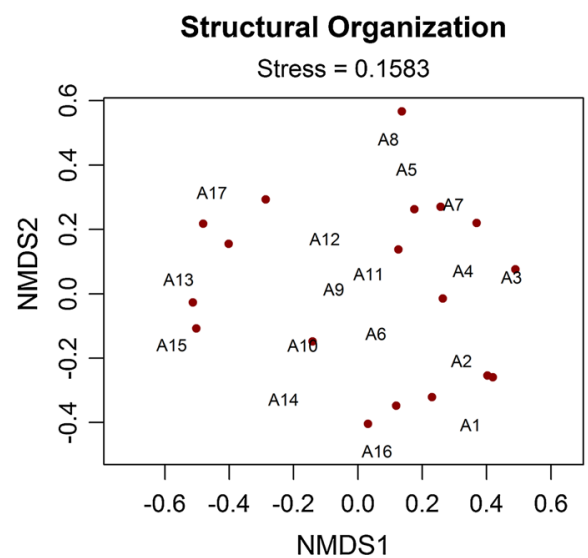

Fig. 2 Non-Metric Multidimensional Scaling based on the similarity indexes of Morisita-Horn ("Structural Organization" = quantitative data) and Sorensen ("Compositional Organization" = qualitative data). Both NMDS were performed on two dimensions. Red circles

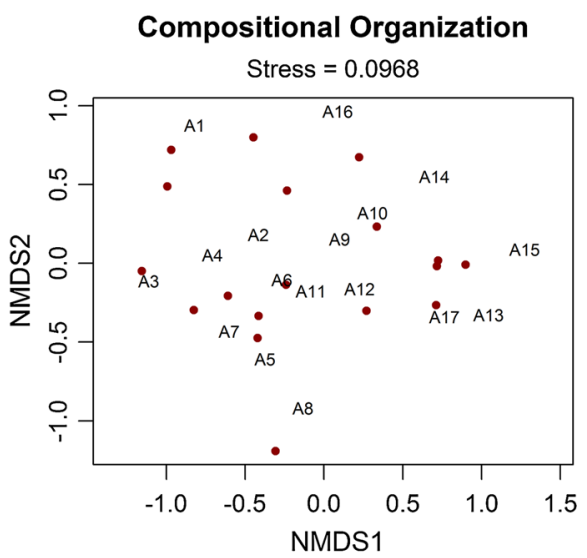

represent the species of social paper wasps collected along the latitudinal gradient. $A 1-A 17$ are the sampled area codes given in Fig. 1. (Color figure online) 
Table 1 Diagnostic parameters of models tested to explain variations in the first axes' site scores of the NMDS estimated with the Morisita-Horn and Sorensen similarity indices, and variations in immigration and speciation probabilities

\begin{tabular}{|c|c|c|c|c|c|c|}
\hline Model & $\mathrm{RV} \sim \mathrm{EVs}$ & $R^{2}$ & $D F$ & $\begin{array}{l}\text { Fixed effects } \\
\text { Estimates (SE) }\end{array}$ & $P$ & R. S. E. \\
\hline \multirow[t]{4}{*}{ GLMMs } & NMDS1 $1_{\text {Horn }} \sim$ latitude & - & 15 & $\begin{array}{l}\text { Intercept: } 0.4661 \\
(0.1293) \\
\text { latitude: }-0.0209 \\
(0.0073)\end{array}$ & $\begin{array}{l}\text { Intercept: } 0.0048^{*} \\
\text { latitude: } 0.0167^{*}\end{array}$ & 0.18353 \\
\hline & NMDS $2_{\text {Horn }} \sim$ latitude & - & 15 & $\begin{array}{l}\text { Intercept: }-0.0560 \\
\quad(0.2227) \\
\text { latitude: } 0.0038(0.0118)\end{array}$ & $\begin{array}{l}\text { Intercept: } 0.8057 \\
\text { latitude: } 0.7561\end{array}$ & 0.28542 \\
\hline & $\mathrm{NMDS}_{\text {Sorensen }} \sim$ latitude & - & 15 & $\begin{array}{l}\text { Intercept: }-1.5631 \\
\quad(0.2614) \\
\text { latitude: } 0.0848(0.0134)\end{array}$ & $\begin{array}{l}\text { Intercept: }<0.001^{*} \\
\text { latitude: }<0.001^{*}\end{array}$ & 0.35943 \\
\hline & $\mathrm{NMDS} 2_{\text {Sorensen }} \sim$ latitude & - & 15 & $\begin{array}{l}\text { Intercept: } 0.0240 \\
\quad(0.3713) \\
\text { latitude: }-0.0018 \\
(0.0191)\end{array}$ & $\begin{array}{l}\text { Intercept: } 0.9494 \\
\text { latitude: } 0.9245\end{array}$ & 0.50806 \\
\hline \multirow[t]{4}{*}{ GAMMs } & $\begin{array}{l}\mathrm{NMDS}_{\text {Horn }} \sim \\
\quad \text { latitude } * \text { altitude }+t e(\log (m))+t e(\log (v))\end{array}$ & 0.838 & 8 & $\begin{array}{l}\text { Intercept: } 0.3086 \\
\text { latitude: }-0.0109 \\
\text { altitude: } 0.0025 \\
\text { latitude:altitude: } \\
\quad-0.0001 \\
\text { te }(\log (m)):-0.213 \\
\text { te }(\log (v)):-1.965\end{array}$ & $\begin{array}{l}\text { Intercept: }<0.001^{*} \\
\text { latitude: }<0.001^{*} \\
\text { altitude: }<0.001^{*} \\
\text { latitude:altitude: } \\
\quad<0.001^{*} \\
\text { te }(\log (m)):<0.001^{*} \\
t e(\log (v)):<0.001^{*}\end{array}$ & - \\
\hline & $\begin{array}{l}\mathrm{NMDS}_{\text {Sorensen }} \sim \\
\quad \text { latitude } * \text { altitude }+t e(\log (m))+t e(\log (v))\end{array}$ & 0.942 & 8 & $\begin{array}{l}\text { Intercept: }-0.7113 \\
\text { latitude: } 0.0275 \\
\text { altitude: }-0.0062 \\
\text { latitude:altitude: } 0.0003 \\
t e(\log (m)): 2.146 \\
t e(\log (v)): 2.053\end{array}$ & $\begin{array}{l}\text { Intercept: }<0.001^{*} \\
\text { latitude: }<0.001^{*} \\
\text { altitude: }<0.001^{*} \\
\text { latitude:altitude: } \\
\quad<0.001^{*} \\
\text { te }(\log (m)):<0.001^{*} \\
\text { te }(\log (v)):<0.001^{*}\end{array}$ & - \\
\hline & $\begin{array}{l}\log (m) \sim s(\text { latitude })+s(\text { altitude })+t e(\text { latitude } \\
\text { altitude })\end{array}$ & 0.934 & 10 & $\begin{array}{l}\text { Intercept: }-2.4410 \\
s \text { (latitude): }-416.1000 \\
s \text { (altitude): } 170.1000 \\
\text { te(latitude:altitude): } \\
216.7000\end{array}$ & $\begin{array}{l}\text { Intercept: }<0.001^{*} \\
s \text { (latitude): }<0.001^{*} \\
s \text { (altitude): }<0.001^{*} \\
\text { te(latitude:altitude): } \\
\quad<0.001^{*}\end{array}$ & - \\
\hline & $\begin{array}{l}\log (v) \sim s(\text { latitude })+s(\text { altitude })+t e(\text { latitude } \\
\text { altitude })\end{array}$ & 0.811 & 10 & $\begin{array}{l}\text { Intercept: }-3.0650 \\
t e \text { (latitude): }-10.3630 \\
\text { te(altitude): }-39.2850 \\
t i \text { (latitude:altitude): } \\
\quad-5.2980\end{array}$ & $\begin{array}{l}\text { Intercept: }<0.001^{*} \\
s(\text { latitude }):<0.001^{*} \\
s(\text { altitude }):<0.001^{*} \\
\text { te (latitude:altitude): } \\
\quad<0.001^{*}\end{array}$ & - \\
\hline
\end{tabular}

$R V$ response variable; $E V s$ explanatory variables; $\log (m)$ immigration probability in logarithmic scale; $\log (v)$ speciation probability in $\operatorname{loga}$ rithmic scale; te smoothing full tensor for the generalized additive mixed models (GAMMs); GLMMs generalized linear mixed models

* significant probabilities

the dependent and independent variables (Table 1), and no significant differences with that model with the lowest AIC (ANOVA: Likelihood Ratio $=3.0643 ; \quad P=0.6901$ ). However, the model which only included altitude as an independent variable was the best-fitting one based on AIC, the variation in $m$ was mainly explained by the interaction between latitude and altitude (see Online Resource 3 for more information). According to the most complete model, $m$ shows linear and positive relationships with the latitudinal variation and negative relationships with altitude (Fig. 4). Considering the AIC values, variations in $v$ would be best explained by the latitudinal gradient, independently of the spatial correlation structure (see Online Resource 3 for details). However, there was no significant difference between that model and the most complete one with a linear spatial correlation structure (ANOVA: Likelihood 
Fig. 3 Relationships between the first axes' site scores of the NMDS (NMDS1) based on Morisita-Horn ("Structural ("Compositional

Organization") indexes with the speciation $(v)$ and immigration $(m)$ probabilities on a logarithmic scale. Al-A17 are the sampled area codes given in Fig. 1 Organization") and Sorensen

Structural Organization
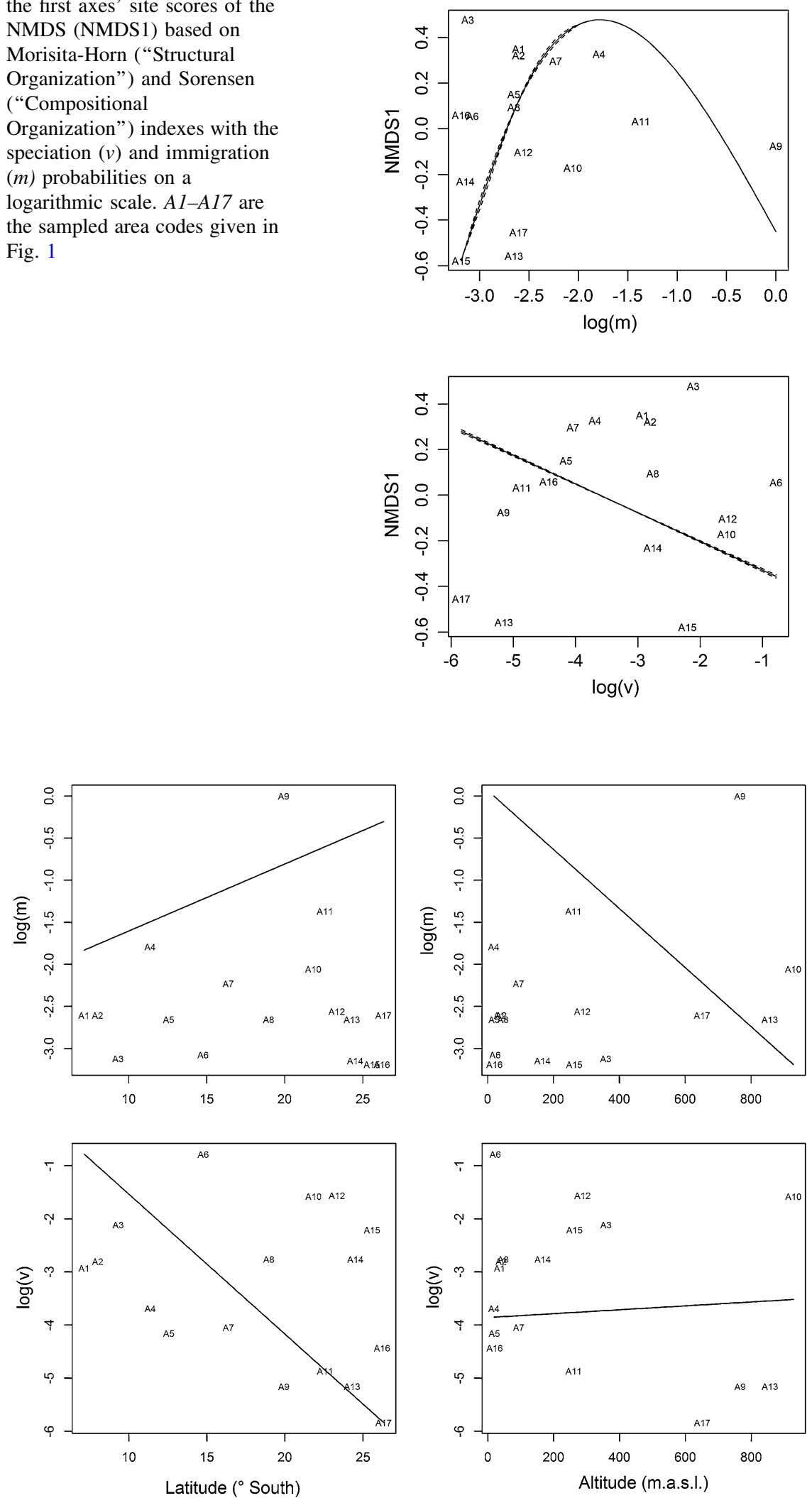
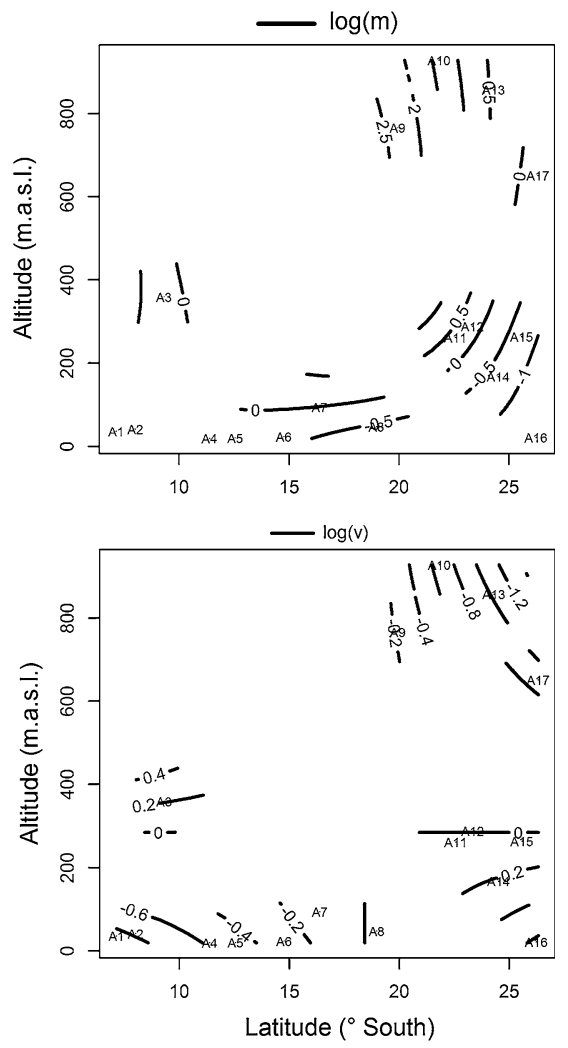

Fig. 4 Variations in the speciation $(v)$ and immigration $(m)$ probabilities on a logarithmic scale along the latitudinal gradient sampled in the Atlantic Forest. Al-A17 are the sampled area codes given in Fig. 1 
Structural Partitioning

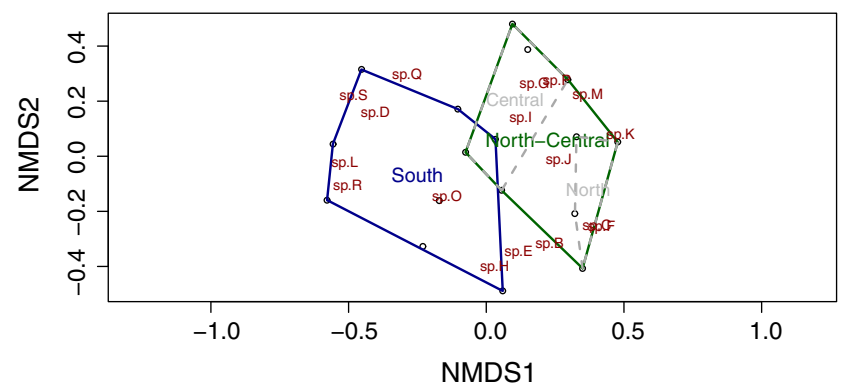

Null Model - Structural Partitioning

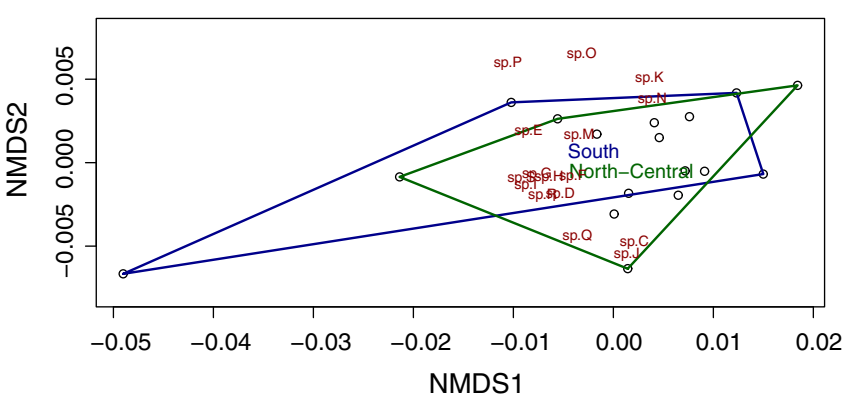

Compositional Partitioning

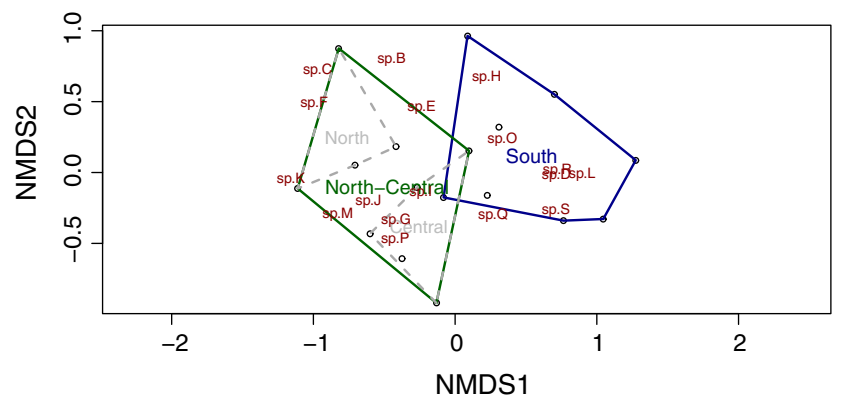

Null Model - Compositional Partitioning

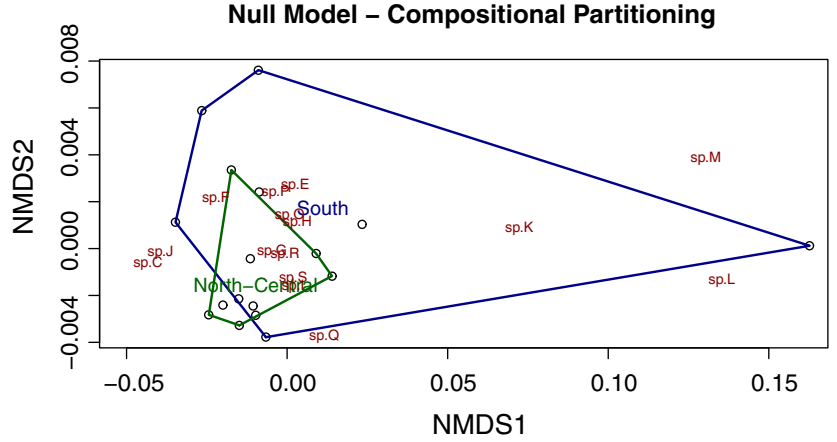

Fig. 5 Graphic representation of fauna partitioning based on species abundance ("Structural Partitioning") and species presence ("Compositional Partitioning")

Ratio $=1.6503 ; P=0.8951)$. In contrast to the variation in $m, v$ shows a negative linear relationship with the latitudinal gradient and a slight positive relationship with variation in altitude (Fig. 4).

\section{Faunistic partitioning}

ANOSIM indicated that the assemblage of social paper wasps was structurally $(R=0.430 ; P=0.001)$ and compositionally $(R=0.435 ; P=0.0005)$ partitioned into two biodiversity centers (Fig. 5). There was no significant difference between the northern and central centers for either the assemblage structure $(R=0.125 ; P=0.166)$ or the composition $(R=0.203 ; P=0.126)$. The null models indicated that both the structural (average Morisita-Horn distance among areas $=0.7255$, Null model $=0.2771$, $P<0.001$ ) and compositional (average Sorensen distance among areas $=0.7333$, Null model $=0.8041, P<0.001$ ) partitions were significantly distinct along the latitudinal gradient (Fig. 5).

\section{Discussion}

The present study did not intend to generate a checklist of Polistinae, but to test whether the structure of the paper wasp assemblage fits the biodiversity centers proposed for conservation of the Atlantic Forest, using a rapid biodiversity assessment protocol. In this way, this study documents that the social paper wasp assemblage is structurally arranged as a continuum along the Atlantic Rain Forest, showing a broad species overlap, as a result of the continuous integration of most communities along the gradients (Whittaker 1975). In fact, Gonçalves and Brandão (2008) found similar results for Meliponina bees along the same latitudinal gradient. However, our results also indicated a significant variation in the structure and composition of the social paper wasp assemblage along the gradient, resulting in two different biodiversity centers (North-Center and South-Fig. 5). In this way, the structural and compositional variation in the social paper wasp assemblage fits the boundary limits of the central and southern biodiversity centers proposed for the Atlantic Rain Forest (Conservation International-Brazil et al. 2000; Fonseca et al. 2003; Ayres et al. 2005).

Carnaval and Moritz (2008) verified that the number of biodiversity centers might vary by group and can be the result of ecological differences and dispersal capability. Diversity patterns of taxonomic groups with poor dispersal abilities are more susceptible to historical effects (Graham et al. 2006). The immigration probability $(m)$ was very strong for the composition, as well as for the assemblage structure. Immigration depends on regional processes such as the generation and dispersal of new species, historical 
factors such as past climate history and the geographical position of dispersal barriers and corridors (Ricklefs 1987). In addition, several other factors, intrinsic and/or extrinsic to the community, might have influenced the fitting to the boundary limits between the northern and central corridors. Intrinsically, such factors may be linked to the biogeographic history of the species that make up the community. The climatic history of the Atlantic Forest determined different events of forest contraction and expansion, which resulted respectively in population isolation and spread (Pennington et al. 2004; Carnaval and Moritz 2008). These events established connections between the Atlantic Forest and the Amazonian Forest at different times and in different regions along the latitudinal gradient (Por 1992; Costa 2003), and allowed the transiting of biota between those two forests, which influenced the current biodiversity patterns in both biomes (Por 1992; Costa 2003).

Some social paper wasps are widely distributed in the Atlantic Forest, and some of them may be found in other biomes. Two of the most abundant species, Agelaia angulata and Angiopolybia pallens, have also been recorded in the Amazonian forest (Morato et al. 2008; Silveira 2002; Silveira et al. 2008; Silva and Silveira 2009), whereas two of the other most abundant species, A. multipicta and A. vicina, range to the Atlantic Semideciduous Forest (Tanaka-Júnior and Noll 2011; Gomes and Noll 2009), but are restricted to the Atlantic Forest. These two and other paper wasp species restricted to the Atlantic Forest might have their origin linked to the forest retractions. The five most abundant species are facultatively necrophagous and feeding on dead vertebrates and large invertebrates (Miller 1993), and because of this such species have been regarded as an important component of this ecosystem (Oliveira et al. 2010).

Based on a phylogeographic study, Carvalho et al. (2014) have noted that A. pallens and Synoeca surinama (Linneaus) are widely and continuously distributed in Central Brazil as a result of a Cenozoic connection between the Amazon and the Atlantic Forest. The current distributions of these two species are somewhat different, as $A$. pallens is restricted to moist forests, whereas $S$. surinama has been recorded in savannas and dry forests as well (Carvalho et al. 2014). Moreover, Carvalho et al. (2014) have noted that the genetic variants of A. pallens and $S$. surinama from the northern biodiversity center of the Atlantic Forest are included in the population from the central center, corroborating the present results.

Extrinsically, the forest fragmentation generated by anthropogenic action might have influenced the diversity pattern reported by this study. Santos et al. (2008) and Lôbo et al. (2011) have shown that the flora of the Atlantic Forest of northeastern Brazil has suffered homogenization, with a loss of functional attributes due to forest fragmentation. Herbivore species, such as the prey of social wasps, might show variable responses to forest fragmentation, but predators are negatively affected by it (Davies et al. 2001). Ranta et al. (1998) have noted that fragments of the Atlantic Rain Forest in northeastern Brazil are relatively small and located close to each other, with only approximately $7 \%$ of the fragments being larger than 100 hectares. According to Hanski (1998), the total amount of habitat in the fragmented landscape is often a good predictor of long-term metapopulation persistence. Despite this, studies targeted at the influence of forest fragmentation on the pattern of diversity are necessary to confirm this assumption.

The small size, allied with irregular shape, of fragments leads to a rapid decrease in the forest core and, consequently, an increase in the edge width (Ranta et al. 1998). The edge effect affects the forest microclimate and, consequently, the structures of plant and animal communities (Didham et al. 1998; Didham and Lawton 1999; Laurance et al. 2002, 2006, 2007; Ries et al. 2004). Currently, the Atlantic Rain forest in the Zona da Mata in the northeastern Brazil mainly consists of edge habitat (Ranta et al. 1998), indicating that the existing fragments should be expanded. Habitat loss increases the local extinction risk and reduces the colonization rate (Comins et al. 1992; Hanski 1998; Gardner and Engelhardt 2008), which could explain the positive relationships between $m$ and the latitudinal gradient. Chust et al. (2013) pointed out that $m$ is relatively constant between $0^{\circ}$ and around $35^{\circ}$ of latitude south, and increases rapidly at higher latitudes.

The present results indicated that both structural and compositional repeatability along the latitudinal gradient are strongly correlated to $m$, which incorporates dispersal limitation (Rosindell et al. 2011) and is regulated by stochastic speciation-extinction processes at the regional level (Hubbell 2001; Chave 2004; Etienne and Alonso 2007; Economo and Keitt 2008). Random extinction and speciation events coupled with the dispersal rate integrate the neutral dynamics of the ecological communities and can explain many of their properties, including species coexistence and biodiversity variations (Hubbell 2001; Volkov et al. 2003; Chave 2004; Etienne and Alonso 2007; Gotelli and McGill 2006). Dispersal rates are affected by the distances between areas and by increased connectivity levels of local communities such that similarities among such communities are increased under multiple stable equilibria as the result of stochastic processes (Chase 2003). In general, fragments in the northern gradient, which demonstrate the lowest connectivity levels, presented lower values of $m$, indicating that the similarities among the paper wasp assemblages in that region are governed by intrinsic ecological processes, such as those predicted by the neutral theory. The community 
correlations among sites established by species coexistence as a result of neutral processes can be strong, extensive and persistent, notably when historical effects are preserved by large communities or low immigration rates (Bell 2000). Thus, the proportions of local births and immigration rates exert important effects on the community structure and composition of the affected habitat, and they are regarded as essential parameters for ecosystem management and conservation strategies (Dornelas 2010).

In contrast to $m, v$ demonstrates different relationships to structural and compositional variations such that, in general, the southern areas of the gradient experience fewer speciation effects than the northern areas, since $v$ decreases southward (Fig. 4). The speciation probability represents the chance that a new species arises in the community from a random mutation (Hubbell 2001; Etienne and Alonso 2007; Economo and Keitt 2008; Kopp 2010), and it is directly proportional to the relative abundance of species in a metacommunity (Etienne et al. 2007). Campos et al. (2012) have noted that habitat fragmentation might result in less sensitivity in the relationships between species-area and $v$, suggesting that biodiversity generation in a disturbed habitat is mainly established by ecological drift. The influence of ecological drift is greater in small areas, since how smaller is the community greater is its susceptibility to stochastic processes inherent to individual birth and death (Bell 2000; Hubbell 2001; Chave 2004; Vellend 2010). Lennon et al. (2001) have reported that areas with low species richness demonstrate greater species turnover, as observed for the Center of Environmental Studies and Research of Vila da Glória in São Francisco do Sul, SC (A16), which was quite similar to northern areas of the gradient, mainly to Mata do Buraquinho in João Pessoa, PB (A1) (Fig. 2). The area in São Francisco do Sul is one of the smallest and most impacted areas included in the present study, since it presented the lowest abundance (15 specimens) and species richness (2 species). Despite the strong fragmentation of the Atlantic Forest in northeastern Brazil, the social paper wasp fauna from that region still incorporates ecological and historical processes intrinsic to the Atlantic Forest (Fig. 5).

In conclusion, considering both historical and ecological processes, this study suggests that the social paper wasp assemblage is structurally organized into two biodiversity centers. To be effective in guiding biome management, the present results should be considered in association with the results of other basic and applied studies and with socioeconomic aspects, providing sustainable development in Brazil. The connection between science and policy has been strongly reinforced by the Millennium Ecosystem Assessment (2005); however, approaches to ecosystem services have been somewhat incomplete, whereas historical aspects of landscapes have been not considered adequately (Joly et al. 2014; Bürgi et al. 2015). Joly et al. (2014) highlighted that to protect and restore the Atlantic Forest, research on this biome should go beyond the understanding of biodiversity patterns and ecological processes, being necessary to comprise, on the basis of basic and applied dimensions, how the forest responds to anthropogenic actions at multiple levels of biological organization and spatial-temporal scales. Assuming that a significant fraction of tropical forest biodiversity depends on undisturbed habitats and landscape connectivity, the ecosystem services provided by anthropogenic landscapes can be significantly augmented by coupling ecological corridor initiatives with any attempt to plug existing gaps in the representativeness of protected areas (Tabarelli et al. 2010). Corridors and stepping-stones have become a significant factor in conservation management systems, and they potentially increase the total area of available habitat (MacDonald 2003; Joly et al. 2014) and allow immigration and gene flow between areas (Tewksbury et al. 2002; Bennett 2003; Ayres et al. 2005). In this way, the biodiversity center approach creates a favorable environment to integrate the ambitious pool of ongoing conservation actions in the Atlantic Forest, including the consolidation of the regional scale corridors, which link distant areas and have already been implemented throughout the Atlantic Forest region (Aguiar et al. 2003; Tabarelli et al. 2010). In fact, habitat corridors have come to represent the basic foundation of any effective biodiversity conservation strategy in highly fragmented forest biota (Beier and Noss 1998; Santos et al. 2008), increasing landscape connectivity and reestablishing or maintaining the structural and functional processes that drive the ecosystem dynamics (Bennett 2003; Elmqvist et al. 2004; Massol et al. 2011).

Acknowledgments We are grateful to Fernando Gellin and Getúlio Tanaka for assistance with species identification and to the collaborators of the major project of which this study constitutes a component. We thank the two referees and the editors John W. Dover and Martin Goßner for the suggestions. This study was supported by the São Paulo Research Foundation (Fapesp; grant numbers: 98/05083-0; 01/08060-5). We dedicate this paper to our colleague, the late Dr. Sérvio T. P. Amarante, who helped to design the collection protocol and took part in several collection trips, the results of which are reported here.

\section{References}

Ab'Saber A (2003) Os Domínios de Natureza no Brasil: potencialidades paisagísticas. Ateliê Editorial, São Paulo

Aguiar PA, Chiarello AG, Mendes SL, Matos LN (2003) The Central and Serra do Mar corridors in the Brazilian Atlantic Forest. In: Galindo-Leal C, Câmara IG (eds) The Atlantic Forest of South America: biodiversity status, threats, and outlook. Island Press, Washington, DC, pp 118-132

Anderson MJ, Willis TJ (2003) Canonical analysis of principal coordinates: a useful method of constrained ordination for ecology. Ecology 84:511-525 
Araújo MB, Nogués-Bravo D, Diniz-Filho JAF, Haywood AM, Valdes PJ, Rahbek C (2008) Quaternary climate changes explain diversity among reptiles and amphibians. Ecography 31:8-15

Ayres JM, Fonseca GAB, Rylands AB, Queiroz HL, Pinto LP, Masterson D, Cavalcanti RB (2005) Os corredores ecológicos das florestas tropicais do Brasil. Sociedade Civil Mamirauá, Belém

Barthelemy Y, Patrice S, Salifou T, Jeanne M-R, Victor H (2015) Floristic diversity of Piliostigma associations in relation to latitudinal gradient, soil and climate variables in Burkina Faso, West Africa. Trop Ecol 56:57-76

Beier P, Noss RD (1998) Do habitat corridors provide connectivity? Conserv Biol 12:1241-1252

Bell G (2000) The distribution of abundance in neutral communities. Am Nat 155:606-617

Bennett AD (2003) Linkages in the landscape: the role of corridors and connectivity in wildlife conservation. IUCN, Gland

Bigarella JJ, Andrade-Lima D, Riehs PJ (1975) Considerações a respeito das mudanças paleoambientais na distribuição de algumas espécies vegetais e animais no Brasil. Acad Bras Ciênc 47:411-464

Brehm G, Fiedler K (2004) Ordinating tropical moth ensembles from an elevational gradiente: a comparison of common methods. J Trop Ecol 20:165-172

Buckley LB, Jetz W (2008) Linking global turnover of species and environments. PNAS 105:17836-17841

Bürgi M, Silbernagel J, Wu J, Kienast F (2015) Linking ecosystem services with landscape history. Landscape Ecol 30:11-20

Campos PRA, Neto EDC, Oliveira VM, Gomes MAF (2012) Neutral communities in fragmented landscapes. Oikos 11:1737-1748

Carnaval AC, Moritz C (2008) Historical climate modelling predicts patterns of current biodiversity in the Brazilian Atlantic forest. J Biogeogr 35:1187-1201

Carvalho AF, Menezes RST, Miranda EA, Costa MA, Carnaval AC, Del Lama MA (2014) Witnesses of the broadest Neotropical disjunction and their idiosyncratic responses to climate change. In: Carvalho AF (ed) Sobre a biogeografia dos polistíneos neotropicais: uma abordagem ecológica e evolutiva. Dissertation, Universidade Federal de São Carlos, pp 67-143

Caswell H (1976) Community structure: a neutral model analysis. Ecol Monogr 46:327-354

CEPF (2001) Ecosystem Profile: Atlantic Forest Hotspot, Brazil. http://www.cepf.netDocumentsfinal.atlanticforest.ep.pdf. Accessed 17 July 2015

Chase JM (2003) Community assembly: when should history matter?. Oecologia 136:489-498

Chave J (2004) Neutral theory and community ecology. Ecol Lett 7:241-253

Chust G, Irigoien X, Chave J, Harris R (2013) Latitudinal phytoplankton distribution and the neutral theory of biodiversity. Global Ecol Biogeogr 22:531-543

Comins HN, Hassell MP, May RM (1992) The spatial dynamics of host-parasitoid systems. J Anim Ecol 61:735-748

Conservation International-Brazil, Fundação SOS Mata Atlântica, Fundação Biodiversitas, Instituto de Pesquisas Ecológicas, Secretaria do Meio Ambiente do Estado de São Paulo, Semad/Instituto Estadual de Florestas-MG (2000) Avaliação e ações prioritárias para a conservação da biodiversidade da Mata Atlântica e Campos Sulinos. Brasília: MMA/SBF. http://www.conservation.org.br/pub licacoes/files/Sumario.pdf. Accessed 20 March 2013

Costa LP (2003) The historical bridge between the Amazon and the Atlantic Forest of Brazil: a study of molecular phylogeograpgy with small mammals. J Biogeogr 30:71-86

Coudrain V, Herzog F, Entling MH (2013) Effects of habitat fragmentation on abundance, larval food and parasitism of a spider-hunting wasp. Plos One 8:e59286. doi:10.1371/journal.pone.0059286
Davies KF, Melbourne BA, Margules CR (2001) Effects of withinand between-Patch processes on community dynamics in a fragmentation experiment. Ecology 82:1830-1846

Didham RK, Lawton JH (1999) Edge structure determines the magnitude of changes in microclimate and vegetation structure in tropical forest fragments. Biotropica 31:17-30

Didham RK, Hammond PH, Lawton JH, Eggleton P, Stork NE (1998) Beetle species responses to topical forest fragmentation. Ecol Monogr 68:295-323

Dornelas M (2010) Disturbance and change in biodiversity. Philos T Roy Soc B 365:3719-3727

Economo EP, Keit TH (2008) Species diversity in neutral metacommunities: a network approach. Ecol Lett 11:52-62

Elmqvist T, Berkes F, Folke C, Angelstam P, Crépin A-S, Niemelã J (2004) The Dynamics of ecosystems, biodiversity, management and social institutions at high northern latitudes. Ambio 33:350-355

Etienne RS (2007) A neutral sampling formula for multiple samples and an exact test of neutrality. Ecol Lett 10:608-618

Etienne RS, Alonso D (2007) Neutral community theory: how stochasticity and dispersal-limitation can explain species coexistence. J Stat Phys 128:485-510

Etienne RS, Haegeman B (2011) The neutral theory of biodiversity with random fission speciation. Theor Ecol 4:87-109

Etienne RS, Apol MEF, Olff H, Weissing FJ (2007) Modes of speciation and the neutral theory of biodiversity. Oikos 116:241-258

Fonseca GAB, Alger K, Pinto LP, Araújo M, Cavalcanti R (2003) Corredores de biodiversidade: o Corredor Central da Mata Atlântica. In: Prado PI, Landau EC, Moura RT, Pinto LPS, Fonseca GAB, Alger K (org) Corredor de Biodiversidade da Mata Atlântica do Sul da Bahia. IESB / CI / CABS / UFMG / UNICAMP Corredores de biodiversidade: o Corredor Central da Mata Atlântica, pp 1-11. http://programas.inema.ba.gov.br/ sigbiota/iesb/Documentos/Corredores\%20de\%20Biodiversidade. pdf. Accessed 18 July 2015

Fundação SOS Mata Atlântica, INPE (2014) Atlas dos remanescentes florestais da Mata Atlântica: Período 2012-2013. http://mapas. sosma.org.br/site_media/download/atlas_2012-2013_relatorio_ tecnico_2014.pdf. Accessed 20 February 2015

Galindo-Leal C, Câmara IG (2003) Atlantic Forest hotspots status:an overview. In: Galindo-Leal C, Câmara IG (eds) The Atlantic Forest of South America: biodiversity status, threats, and outlook. Center for Applied Biodiversity Science and Island Press, Washington, D.C., pp 3-11

Gardner RH, Engelhardt KAM (2008) Spatial processes that maintain biodiversity in plant communities. Perspect Plant Ecol 9: 211-228

Gaston KJ (2003) The structure and dynamics of geographic ranges. Oxford University Press, New York

Gaston KJ, Williams PH (1996) Spatial patterns in taxonomic diversity. In: Gaston KJ (ed) Biodiversity: a biology of numbers and difference. Blackwell Science, Oxford, pp 202-229

Goldberg EE, Lande R (2007) Species' borders and dispersal barriers. Am Nat 170:297-304

Gomes B, Noll FB (2009) Diversity of social wasps (Hymenoptera, Vespidae, Polistinae) in three fragments of semideciduous seasonal forest in the northwest of São Paulo State, Brazil. Rev Bras Entomol 53:428-431

Gonçalves RB, Brandão CRF (2008) Diversity of bees (Hymenoptera, Apidae) along a latitudinal gradient in the Atlantic Forest. Biota Neotrop 8:51-61

Gotelli NJ, Graves GR (1996) Null models in ecology. Smithsonian Institution Press, Washington, DC

Gotelli NJ, McGill BJ (2006) Null versus neutral models: what's the difference? Ecography 29:793-800 
Gower JC (1987) Introduction to ordination techniques. In: Legendre $\mathrm{P}$, Legendre L (eds) Developments in numerical ecology, vol 14., NATO ASI SeriesSpringer-Verlag, Berlin, pp 3-64

Graham CH, Moritz C, Williams SE (2006) Habitat history improves prediction of biodiversity in rainforest fauna. PNAS 103:632636

Haegeman B, Etienne RS (2010) Self-consistent approach for neutral community models with speciation. Phys Rev E 81:031911

Hankin RKS (2015) Package untb version 1.7-2: Ecological drift under the UNTB. http://cran.r-project.org/web/packages/untb/ untb.pdf. Accessed 23 February 2015

Hanski I (1998) Metapopulation dynamics. Nature 396:41-49

Hawkins BA, Porter EE, Diniz-Filho JAF (2003) Productivity and history as predictors of the latitudinal diversity gradient of terrestrial birds. Ecology 84:1608-1623

Hubbell SP (2001) The unified neutral theory of biodiversity and biogeography. Princeton University Press, Princeton

Huston MA (1994) Biological Diversity: the coexistence of species on changing landscapes. Cambridge University Press, New York

Joly CA, Metzger JP, Tabarelli M (2014) Experiences from the Brazilian Atlantic Forest: ecological findings and conservation initiatives. New Phytol 204:459-473

Kopp M (2010) Speciation and the neutral theory of biodiversity: modes of speciation affect patterns of biodiversity in neutral communities. BioEssays 32:564-570

Laurance WF, Lovejoy TE, Heraldo LV, Bruna EM, Didham RK, Stouffer PC, Gascon C, Bierregaard RO, Laurance SG, Sampaio E (2002) Ecosystem decay of Amazonian Forest fragments: a 22-year investigation. Conserv Biol 16:605-618

Laurance WF, Nascimento HEM, Laurance SG, Andrade A, Ribeiro JELS, Giraldo JP, Lovejoy TE, Condit R, Chave J, Harms KE, D'Angelo S (2006) Rapid decay of tree-community composition in Amazonian forest fragments. PNAS 103:19010-19014

Laurance WF, Nascimento HEM, Laurance SG, Andrade A, Ewers RM, Harms KE, Luizão RCC, Ribeiro JE (2007) Habitat fragmentation, variable edge effects, and the landscape-divergence hypothesis. PLoS ONE 2:e1017

Laurence WF (2009) Conserving the hottest of the hotspots. Biol Conserv 142:1137

Legendre P, Legendre L (1998) Numerical ecology. Elsevier, Amsterdam

Leibold MA, Holyoak M, Mouquet N, Amarasekare P, Chase JM, Hoopes MF, Holt RD, Shurin JB, Law R, Tilman D, Loreau M, Gonzalez A (2004) The metacommunity concept: a framework for multi-scale community ecology. Ecol Lett 7:601-613

Lennon JJ, Koleff P, Greenwood JJD, Gaston KJ (2001) The geographical structure of British bird distributions: diversity, spatial turnover and scale. J Anim Ecol 70:966-979

Leprieur F, Tedesco PA, Hugueny B, Beauchard O, Dürr HH, Brosse S, Thierry O (2011) Partitioning global patterns of freshwater fish beta diversity reveals contrasting signatures of past climate changes. Ecol Lett 14:325-334

Lôbo D, Leão T, Melo FPL, Santos AMM, Tabarelli M (2011) Forest fragmentation drives Atlantic forest of northeastern Brazil to biotic homogenization. Divers Distrib 17:287-296

Maaß S, Migliorini M, Rillig MC, Caruso T (2014) Disturbance, neutral theory, and patterns of beta diversity in soil communities. Ecol Evol 4:4766-4774

MacArthur RH, Wilson EO (1967) The theory of island biogeography. Princeton University Press, Princenton

MacDonald MA (2003) The role of corridors in biodiversity conservation in production forest landscapes: a literature review. Tasforest 14:41-52

Massol F, Gravel D, Mouquet N, Cadotte MW, Fukami T, Leibold MA (2011) Linking community and ecosystem dynamics through spatial ecology. Ecol Lett 14:313-323
McKinney ML (1997) Extinction vulnerability and selectivity: combining ecological and paleontological views. Annu Rev Ecol Syst 28:495-516

Millennium Ecosystem Assessment (2005) Ecosystems and human well-being: synthesis. Island Press, Washington. http://www. millenniumassessment.org/documents/document.356.aspx.pdf. Accessed 02 July 2015

Miller JC (1993) Insect natural history, multi-species interactions and biodiversity in ecosystems. Biodivers Conserv 2:233-241

Minchin PR (1987) An evaluation of the relative robustness of techniques for ecological ordination. Vegetation 69:89-107

Mittermeier RA, Gil PR, Hoffmann M, Pilgrim J, Brooks J, Mittermeier CG, Lamourux J, Fonseca GAB (2004) Hotspots revisited: earth's biologically richest and most endangered terrestrial ecoregions. Cemex, Washington

MMA (2006) Mapa de Cobertura Vegetal da Mata Atlântica: escala 1:250.000. http://www.mma.gov.br/biomas/mata-atlantica/mapade-cobertura-vegetal. Accessed 17 March 2015

Morato EF, Amarante ST, Silveira OT (2008) Avaliação ecológica rápida da fauna de vespas (Hymenoptera: Aculeata) do Parque Nacional da Serra do Divisor, Acre, Brasil. Acta Amaz 38: 789-798

Morellato LPC, Haddad CFB (2000) Introduction: the Brazilian Atlantic Forest. Biotropica 32:786-792

Morrone JJ (2006) Biogeographic areas and transition zones of Latin America and the Caribbean Islands based on panbiogeographic and cladistic analyses of the entomofauna. Annu Rev Entomol 51:467-494

Munoz F, Couteron P, Ramesh BR (2008) Beta diversity in spatially implicit neutral models: a new way to assess species migration. Am Nat 172:116-127

Myers N, Mittermeier RA, Mittermeier CG, Fonseca GAB, Kent J (2000) Biodiversity hotspots for conservation priorities. Nature 403:853-858

Noyes JS (1989) A study of five methods of sampling Hymenoptera (Insecta) in a tropical rainforest, with special reference to the Parasitica. J Nat Hist 23:285-298

Oksanen J, Blanchet FG, Kindt R, Legendre P, Minchin PR, O'Hara B, Simpson GL, Solymos P, Stevens MHH, Wagner H (2013) The vegan Package: version 2.0-8. http://vegan.r-forge.r-project. org/. Accessed 23 February 2015

Oliveira OAL, Noll FB, Wenzel JW (2010) Details on the biology of Agelaia vicina (Hymenoptera: Vespidae; Epiponini) suggest it is a keystone species. J Hymenopt Res 19:4-11

Peel MC, Finlayson BL, McMahon TA (2007) Updated world map of the Köppen-Geiger climate classification. Hydrol Earth Syst Sc 11:1633-1644

Pennington RT, Lavin M, Prado DE, Pendry CA, Pell SK, Butterworth CA (2004) Historical climate change and speciation: neotropical seasonally dry forest plants show patterns of both Tertiary and Quaternary diversification. Philos T Roy Soc B 359:515-537

Pinheiro J, Bates D, DebRoy S, Sarkar D, Smith BT, Boyle JM, Dongarra JJ, Garbow BS, Ikebe Y, Klema VC, Moler CB, R-core team (2015) Package nlme version 3.1-120: linear and nonlinear mixed effects models. http://cran.r-project.org/web/packages/ nlme/nlme.pdf. Accessed 23 February 2015

Pinto LP, Brito MCW (2005) Dinâmica da perda da biodiversidade na Mata Atlântica brasileira: uma introdução. In: Galindo-Leal C, Câmara IG (eds) Mata Atlântica: biodiversidade, ameaças e perspectivas. Fundação SOS Mata Atântica, Conservação International, São Paulo, Belo Horizonte, pp 27-30

Por FD (1992) Sooretama: the Atlantic rain forest of Brazil. SPB Academic Publishing, The Hague

Prance GT (1987) Biogeography of Neotropical plants. In: Whitmore TC, Prance GT (eds) Biogeography and quaternary history in 
Tropical America. Oxford Science Publications, Oxford, pp 46-65

R Development Core Team (2014) R: a language and environment for statistical computing. R Foundation for Statistical Computing, Vienna, Austria. ISBN 3-900051-07-0. http://cran.r-project.org/. Accessed 11 March 2013

Ranta P, Blom T, Niemela J, Joensuu E, Siitonen M (1998) The fragmented Atlantic Rain Forest of Brazil: size, shape and distribution of forest fragments. Biodivers Conserv 7:385-403

Ribeiro MC, Metzger JP, Martensen AC, Ponzoni FJ (2009) The Brazilian Atlantic Forest: how much is left, and how is the remaining forest distributed? Implications for conservation. Biol Conserv 142:1141-1153

Richards OW (1978) The social wasps of the Americas excluding the Vespinae. British Museum Natural History, London

Ricklefs RE (1987) Community Diversity: Relative Roles of Local and Regional Processes. Science 235:167-171

Ricklefs RE (2004) A comprehensive framework for global patterns in biodiversity. Ecol Lett 7:1-15

Ricklefs RE (2007) History and diversity: explorations at the intersection of ecology and evolution. Am Nat 170:S56-S70

Ries L, Fletcher RJ, Batttin J, Sisk TD (2004) Ecological responses to habitat edges: mechanisms, models, and variability explained. Annu Rev Ecol Evol S 35:491-522

Rosindell J, Cornell SJ, Hubbell SP, Etienne RS (2010) Protracted speciation revitalizes the neutral theory of biodiversity. Ecol Lett 13:716-727

Rosindell J, Hubbell SP, Etienne RS (2011) The unified neutral theory of biodiversity and biogeography at age ten. Trends Ecol Evol 26:340-348

Sandel B, Arge L, Dalsgaard B, Davies RG, Gaston KJ, Sutherland WJ, Svenning JC (2011) The influence of late Quaternary climate-change velocity on species endemism. Science 334:660-664

Santos BA, Peres CA, Oliveira MA, Grillo A, Alves-Costa CP, Tabarelli M (2008) Drastic erosion in functional attributes of tree assemblages in Atlantic forest fragments of northeastern Brazil. Biol Conserv 141:249-260

Santos EF, Noll FB, Brandão CRF (2014) Functional and taxonomic diversity of stinging wasps in Brazilian Atlantic Rainforest areas. Neotrop Entomol 43:97-105

Sarmiento CE (2004) A test of adaptive hypotheses: mandibular traits, nest construction materials, and feeding habits in neotropical social espas (Vespidae, Polistinae). Insect Soc 51:387-391

Schwartz MW, Iverson LR, Prasad AM, Matthews SN, O'Connor RJ (2006) Predicting extinctions as a result of climate change. Ecology 87:1611-1615

Silva JMC, Casteleti CH (2003) Status of the biodiversity of the Atlantic Forest of Brazil. In: Galindo-Leal C, Câmara IG (eds) The Atlantic Forest of South America: biodiversity status, threats, and outlook. Island Press, Washington, DC, pp 43-59

Silva SS, Silveira OT (2009) Vespas sociais (Hymenoptera, Vespidae, Polistinae) de floresta pluvial Amazônica de terra firme em Caxiuanã, Melgaço, Pará. Iheringia 99:317-323

Silveira OT (2002) Surveying Neotropical Social Wasps. An evaluation of methods in the "Ferreira Penna" research station
(ECFPn), in Caxuanã, PA, Brazil (Hym., Vespidae, Polistinae). Pap Avulsos Zool 42:299-323

Silveira OT, Costa-Neto SV, Silveira OFM (2008) Social wasps of two wetland ecosystems in Brazilian Amazonia (Hymenoptera, Vespidae, Polistinae). Acta Amaz 38:333-344

Tabarelli M, Pinto LP, Silva JMC, Hirota M, Bedê L (2005) Challenges and opportunities for biodiversity conservation in the Brazilian Atlantic Forest. Conserv Biol 19:695-700

Tabarelli M, Aguiar AV, Ribeiro MC, Metzger JP, Peres CA (2010) Prospects for biodiversity conservation in the Atlantic Forest: lessons from aging human-modified landscapes. Biol Conserv 143:2328-2340

Tanaka-Junior GM, Noll FB (2011) Diversity of social wasps on semideciduous seasonal forest fragments with different surrounding matrix in Brazil. Psyche 2011:1-8

Tewksbury JJ, Levey DJ, Haddad NM, Sargent S, Orrock JL, Weldon A, Danielson BJ, Brinkerhoff J, Damschen EI, Townsend P (2002) Corridors affect plants, animals, and their interactions in fragmented landscapes. PNAS 99:12923-12926

Vellend M (2010) Conceptual synthesis in community ecology. Q Rev Biol 85:183-206

Volkov I, Banavar JR, Hubbell SP, Maritan A (2003) Neutral theory and relative species abundance in ecology. Nature 424:1035-1037

Wenzel JW (1998) A generic key to the nests of hornets, yellow jackets, and paper wasps worldwide (Vespidae: Vespinae, Polistinae). Am Mus Novit 3224:1-39

Whittaker RH (1975) Communities and ecosystems. MacMillan Publishing, New York

Wiens JJ, Donoghue MJ (2004) Historical biogeography, ecology and species richness. Trends Ecol Evol 19:639-644

Willig MR (2001) Latitude, common trends within. In: Levin SA (ed) Encyclopedia of biodiversity, vol 3. Academic Press, Waltham, pp 701-714

Willig MR, Hufman DM, Stevens RD (2003) Latitudinal gradients of biodiversity: patterns, process, scale, and synthesis. Annu Rev Ecol Syst 34:273-309

Willink A (1988) Distribution patterns of Neotropical insects with special reference to the Aculeate Hymenoptera of southern South America. In: Vanzolini PE, Heyer WR (eds) Proceedings of a workshop on Neotropical distribution patterns. Academia Brasileira de Ciências, Rio de Janeiro, pp 205-221

Wood S (2014) Package mgcv version 1.8-4: mixed gam computation vehicle with GCV/AIC/REML smoothness estimation. http:// cran.r-project.org/web/packages/mgcv/mgcv.pdf. Accessed 23 February 2015

Ye D, Hu Y, Song M, Pan X, Xie X, Liu G, Ye X, Dong M (2014) Clonality-climate relationships along latitudinal gradient across China: adaptation of clonality to environments. PLoS ONE 9:e94009

Zucchi R, Sakagami S, Noll FB, Mechi MR, Mateus S, Baio MV, Shima SN (1995) Agelaia vicina, a swarm-founding polistine with the largest colony size among wasps and bees (Hymenoptera: Vespidae). J New York Entomol S 103:129-137 